\title{
PENERAPAN MODEL VISUALIZATION AUDITORY KINESTETIC (VAK) UNTUK MENINGKATKAN HASIL BELAJAR SISWA
}

\author{
Oleh: Isnania Lestari \\ (Dosen IKIP PGRI Pontianak) \\ Email: isnanialestari@gmail.com
}

\begin{abstract}
Abstrak
Penelitian ini bertujuan untuk membuktikan proses pembelajaran menggunakan model Visualization Auditory Kinestetic (VAK) dan peningkatan hasil belajar siswa pada materi menu dan ikon perangkat lunak pengolah kata melalui model Visualization Auditory Kinestetic (VAK) di kelas VIII SMP Negeri 1 Sungai Betung. Metode yang digunakan dalam penelitian ini adalah metode penelitian tindakan kelas atau yang dikenal dengan istilah classroom action research dengan model Kemmis dan Mc Taggart. Bentuk penelitian yang digunakan dalam penelitian ini adalah penelitian tindakan kolaboratif. Teknik analisis data yang digunakan yaitu analisis deskriptif kualitatif. Berdasarkan hasil penelitian pra siklus, siklus I, dan siklus II dapat disimpulkan sebagai berikut: proses pembelajaran TIK di kelas VIII SMP Negeri 1 Sungai Betung menggunakan model Visualization Auditory Kinestetic meningkat dengan baik, hasil pengamatan terhadap guru dan siswa di antaranya siklus I pada lembar penilaian IPKG memperolah rata-rata 3,70 dan observasi siswa memperolah rata-rata skor 2,93, dan siklus II pada lembar penilaian IPKG memperolah ratarata 3,97 dan observasi siswa memperolah rata-rata skor 3,38. Terdapat Peningkatan hasil belajar siswa pada materi menu dan ikon perangkat lunak pengolah kata di kelas VIII SMP Negeri 1 Sungai Betung, hasil tersebut di antaranya pada pra siklus mendapat nilai rata-rata 67,58 dengan ketuntasan klasikal 56,25\%, siklus I dengan nilai rata-rata 72,01 dan hasil persentase ketuntasan klasikal 68,75\%, dan siklus II dengan nilai rata-rata 78,07 dan hasil persentase ketuntasan klasikal 84,38\%.
\end{abstract}

Kata Kunci: Visualization Auditory Kinestetic, Hasil Belajar

\section{APPLICATION OF VISUALIZATION AUDITORY KINESTETIC (VAK) MODEL TO INCREASE STUDENT LEARNING RESULT}

\begin{abstract}
This study aims to prove the learning process using Kinesthetic Visualization Auditory (VAK) model and improving student learning outcomes on menu materials and icons of word processing software through Visualization Auditory Kinestetic (VAK) model in Grade VIII of SMP Negeri 1 Sungai Betung. The method used in this research is classroom action research method or known as classroom action research with Kemmis and Mc Taggart model. The form of research used in this research is collaborative action research. Data analysis technique that is used is descriptive qualitative analysis. Based on the results of
\end{abstract}


pre-cycle research, cycle I, and cycle II can be summarized as follows: ICT learning process in grade VIII SMP Negeri 1 Sungai Betung using Visualization Auditory kinestetic model improved well, the observation of teachers and students such as cycle I on the IPKG assessment sheet average of 3.70 and student observation obtained average score of 2.93, and cycle II on the scoring IPKG score average 3.97 and student observations average score 3.38. There are improvements in student learning results in menu materials and icons word processing software in grade VIII of SMP 1 Sungai Betung, the results of which in the pre cycle gets an average score of 67.58 with $56.25 \%$ classical completeness, the first cycle with an average value 72.01 and the percentage of classical completeness $68.75 \%$, and cycle II with an average value of 78.07 and the percentage of classical completeness $84.38 \%$.

Keywords: Visualization Auditory Kinestetic, Learning Outcomes.

\section{A. PENDAHULUAN}

Satu di antara masalah pokok pendidikan dalam pembelajaran di sekolah saat ini adalah masih rendahnya hasil belajar siswa. Hasil belajar ini tentunya merupakan hasil dari proses pembelajaran di kelas. Karena proses pembelajaran yang masih didominasi oleh guru, maka sedikit banyak mempengaruhi keaktifan siswa dalam proses pembelajaran.

Kegiatan proses belajar mengajar yang terjadi di kelas VIII SMP Negeri 1 Sungai Betung dilakukan guru masih menggunakan model pembelajaran konvensional yaitu pembelajaran dimulai dengan membacakan materi pada buku LKS, dan diselingi buku paket kemudian menjelaskan bagian-bagian yang dianggap penting. Model pembelajaran yang digunakan kurang membuat siswa tertarik untuk mengikuti pembelajaran.

Data hasil belajar mata pelajaran TIK di SMP Negeri 1 Sungaai Betung memperlihatkan bahwa dari 4 kelas VIII di sekolah tersebut, rerata nilai yang diperoleh adalah 67, 58 - 69,60. Angka tersebut belum mencapai KKM sebesar 75. Berdasarkan data tersebut pula didapat bahwa ketuntasan klasikal yang dicapai oleh siswa adalah $44 \%$ - 51\%. Sedangkan pembelajaran dikatakan berhasil jika ketuntasan klasikal yang ditentukan oleh sekolah, yakni $80 \%$.

Berdasarkan data tersebut, peneliti akan mengganti model pembelajaran yang digunakan dalam proses pembelajaran. Ada banyak model pembelajaran yang 
dapat digunakan untuk memnacing keaktifan siswa. Salah satunya adalah model Visualization Auditory Kinestetic (VAK). Marcova dkk (dalam Huda, 2014:287) "ketiga modalitas ini digunakan untuk pembelajaran, pemrosesan,dan komunikasi”. Dengan visual, siswa atau siswa diajak untuk melihat pengetahuan baru yang akan dipelajari dengan pengetahuan yang terdahulu. Misalnya, waktu dulu siswa hanya diajak untuk belajar membayangkan suatu gambar yang sedang diajarkan oleh guru, sedangkan sekarang siswa langsung melihat visual dengan nyata dan secara rinci. Audio, membawa siswa memahami maksud tujuan materi yang telah disampaikan. Kinestethic, siswa dilatih menjelaskan materi secara langsung dengan gerakan seolah siswa belajar dengan nyata sehingga siswa benarbenar paham dengan materi yang di bahas.

Model pembelajaran Visualization Auditory Kinestetic (VAK) menganggap bahwa pembelajaran akan efektif dengan memperhatikan ketiga gaya belajar tersebut, dengan kata lain manfaatkanlah potensi siswa yang telah dimilikinya dengan melatih dan mengembangkannya. Model $V A K$ ini bertujuan menjadikan pembelajar nyaman, sehingga terwujudlah tujuan pembelajaran diinginkan yaitu pembelajaran yang efektif dan efesien sehingga hasil belajar siswa meningkat (Shoimin, 2013).

Secara umum tujuan dari penelitian ini adalah untuk meningkatkan hasil belajar siswa menggunakan model pembelajaran Visualization Auditory Kinestetic (VAK). Secara khusus tujuan yang ingin dicapai dari penelitian ini untuk mengetahui (1). Proses pembelajaran menggunakan model Visualization Auditory Kinestetic (VAK) pada materi menu dan ikon perangkat lunak pengolah kata di kelas VIII SMP Negeri 1 Sungai Betung; (2). Peningkatan hasil belajar siswa pada materi menu dan ikon perangkat lunak pengolah kata melalui model Visualization Auditory Kinestetic (VAK) di kelas VIII SMP Negeri 1 Sungai Betung.

\section{B. METODOLOGI PENELITIAN}

Penelitian ini termasuk penelitian kuantitatif dengan metode yang digunakan dalam penelitian ini adalah metode penelitian tindakan kelas atau yang dikenal dengan istilah classroom action research dengan model Kemmis dan Mc Taggart 
(Mulyasa, 2011). Tujuan dari penelitian tindakan kelas untuk meningkatkan kualitas pembelajaran sehingga tercapai tujuan pembelajaran yang diharapkan. Bentuk penelitian yang digunakan dalam penelitian ini adalah penelitian tindakan kolaboratif (Arikunto, 2014). Subjek penelitian ini adalah guru dan siswa. Kelas yang diambil sebagai subjek penelitian ini adalah kelas VIII D SMP Negeri 1 Sungai Betung dengan jumlah siswa 32 orang, terdiri dari 17 siswa perempuan dan 15 siswa laki-laki. Dalam penelitian ini, tindakan yang dilakukan sebanyak 2 siklus. Prosedur Tindakan dalam penelitian ini adalah sebagai berikut:

1. Perencanaan (Planning); kegiatan yang dilakukan dalam perencanaan sesuai dengan identifikasi masalah yang ditetapkan dengan melakukan rencana pelaksanaan penelitian tindakan kelas.

2. Pelaksanaan (Acting); pelaksanaan tindakan dalam penelitian ini berupa pelaksanaan kegiatan pembelajaran di kelas sesuai dengan skenario pembelajaran yang telah dirancang yaitu menerapkan model pembelajaran Visualization Auditory Kinestetic (VAK).

3. Observasi (Observing); observasi atau pengamatan dilakukan dengan menggunakan lembar observasi dan hasil belajar yang telah dibuat guna mengetahui bagaimana proses pembelajaran dengan menerapkan model Visualization Auditory Kinestetic (VAK), serta untuk mengetahui kendala apa saja yang dihadapi guru selama proses pembelajaran dengan menggunakan model ini.

4. Refleksi (Reflecting); Refleksi dilakukan untuk melihat keseluruhan proses pelaksanaan tindakan dan hasil pengamatan siswa. tahapan ini dimaksudkan untuk mengkaji secara menyeluruh tindakan yang telah dilakukan berdasarkan data yang telah terkumpul kemudian dilakukan evaluasi guna menyampurnakan tindakan berikutnya (Arikunto, 2010).

Instrumen yang digunakan dalam penelitian ini adalah lembar observasi, tes objektif dan juga dokumentasi hasil kegiatan mengajar selama didalam kelas. Data yang telah dikumpulkan melalui instrumen - instrumen tersebut diolah dengan menggunakan teknik analisis deskriptif kualitatif. Data kualitatif yang telah dikumpulkan akan dianalisis dengan teknik analisis interaktif yang dikembangkan 
oleh Miles dan Huberman. Teknik analisis ini terdiri dari empat komponen kegiatan yang saling terkait satu sama lain, yaitu koleksi data, reduksi data yang telah terkumpul, penyajian data, dan penarikan kesimpulan.

Selanjutnya, Indikator keberhasilan dalam penelitian ini adalah ketuntasan klasikal belajar siswa di kelas VIII SMP Negeri 1 Sungai Betung, yakni siswa dinyatakan tuntas jika hasil belajar siswa mendapat nilai lebih dari 75 sebanyak lebih dari 80\%. Siswa yang mencapai nilai KKM 75 harus berjumlah 29 siswa dari 36 orang siswa serta denganketuntasan klasikal mencapai 80,56\%.

Penelitian tindakan kelas ini dapat dikatakan berhasil dan terjadi peningkatan hasil belajar, berdasarkan peningkatan jumlah siswa yang tuntas sebagai indikator ketuntasan klasikal melalui hasil tes formatif. Peningkatan nilai rata-rata dari pra siklus ke siklus I dan siklus I ke siklus II dan ketuntasan klasikal hasil belajar terjadi peningkatan secara bertahap dari mulai pra siklus, siklus I dan siklus II.

\section{HASIL PENELITIAN DAN PEMBAHASAN}

\section{Paparan Pra Siklus}

Pelaksanaan pra siklus ini dilakukan untuk mengetahui kondisi awal siswa pada mata pelajaran TIK. Berdasarkan data hasil belajar pra siklus dapat diketahui bahwa siswa yang tuntas mata pelajaran TIK berjumlah 18 orang $(56,25 \%)$ sedangkan yang tidak tuntas yaitu berjumlah 14 orang $(43,75 \%)$ dengan nilai ratarata 67,58 , masih belum mencapai standar ketetapan yang diberlakukan yaitu $80 \%$ ketuntasan klasikal. Berikut adalah tabel presentase ketuntasan klasikal pra siklus:

Tabel 1. Persentase Ketuntasan Klasikal

\begin{tabular}{|c|l|c|c|}
\hline No & Hasil Belajar Siswa & Jumlah & Persentase \\
\hline 1. & Tuntas & 18 siswa & $56,25 \%$ \\
\hline 2. & Belum Tuntas & 14 siswa & $43,75 \%$ \\
\hline \multicolumn{2}{|c|}{ Jumlah } & 32 siswa & $100 \%$ \\
\hline
\end{tabular}

Berdasarkan data tersebut dapat disimpukan bahwa belum tercapainya ketuntasan klasikal sebesar $80 \%$ yang ditetapkan oleh sekolah sebagai indikator keberasilan dalam pembelajaran. 


\section{Paparan Siklus I}

Kegiatan siklus I dilaksanakan sebanyak dua kali pertemuan. Berdasarkan data hasil belajar siswa siklus I, dapat diketahui bahwa jumlah siswa yang tuntas adalah 22 (68,75\%), sedangkan siswa yang belum lulus adalah 10 (31,25\%). Dengan rata-rata nilai 71,01 . Berikut adalah hasil dari siklus I yang telah dilaksanakan.

Tabel 2. Paparan Siklus I

\begin{tabular}{|c|l|c|c|}
\hline No & Hasil Belajar Siswa & Jumlah & Persentase \\
\hline 1. & Tuntas & 22 siswa & $68,75 \%$ \\
\hline 2. & Belum Tuntas & 10 siswa & $31,25 \%$ \\
\hline \multicolumn{2}{|c|}{ Jumlah } & 32 siswa & $100 \%$ \\
\hline
\end{tabular}

Berdasarkan data tersebut dapat disimpukan bahwa belum tercapainya ketuntasan klasikal sebesar $80 \%$ yang ditetapkan oleh sekolah sebagai indikator keberasilan dalam pembelajaran. Maka dapat disimpulkan bahwa peneliti harus melanjutkan tindakan pada siklus II.

\section{Paparan Siklus II}

Siklus II dilaksanakan berdasarkan hasil dari siklus I pada saat refleksi. Pelaksanaan siklus II dilaksanakan sebanyak dua kali pertemuan. Berdasarkan data hasil belajar siswa siklus II dapat diketahui bahwa jumlah siswa yang lulus adalah 27 siswa $(84,38 \%)$. Sedangkan siswa yang tidak lulus 5 orang (15,62\%) dengan nilai rata-rata 78,07. Berikut adalah hasil dari siklus II yang telah dilaksanakan.

Tabel 3. Paparan Siklus II

\begin{tabular}{|c|l|c|c|}
\hline No & Hasil Belajar Siswa & Jumlah & Persentase \\
\hline 1. & Tuntas & 27 siswa & $84,38 \%$ \\
\hline 2. & Belum Tuntas & 5 siswa & $15,62 \%$ \\
\hline \multicolumn{2}{|c|}{ Jumlah } & 32 siswa & $100 \%$ \\
\hline
\end{tabular}

Berdasarkan data tersebut dapat disimpukan bahwa ketuntasan klasikal telah tercapai yakni sebesar 84,38\%. Hasil data tersebut dapat disimpulkan bahwa pelaksanaan model visualization auditory kinestetic (VAK) di kelas VIII SMP 
Negeri 1 Sungai Betung untuk meningkatkan hasil belajar siswa dinyatakan berhasil karena telah melampaui ketetapan ketuntasan klasikal yaitu > 80\%.

\section{PEMBAHASAN}

Berdasarkan analisis data yang telah dilakukan berikut adalah pembahasan rekapitulasi data pelaksanaan proses pembelajaran menggunakan Visualization Auditory Kinestetic (VAK) di kelas VIII SMP Negeri 1 Sungai Betung yang mengambil materi menu dan ikon perangkat lunak pengolah kata.

\section{Kemampuan Guru dalam Melaksanakan Pembelajaran}

Kemampuan guru dalam melaksanakan pembelajaran pada siklus I dan siklus II terdapat peningkatan yang sangat baik karena bisa dilihat dari rata-rata skor yang diperoleh pada aspek yang diamati, yakni diawal pada tahap kegiatan belajar siswa pada siklus I mendapatkan nilai rata-rata 3,70 (sangat baik) meningkat sebesar pada siklus II yakni 3,97 (sangat baik).

\section{Kegiatan Belajar Siswa}

Jumlah keseluruhan dari empat tahapan pembelajaran yang dilalui siswa dalam kegiatan belajar memperoleh rata-rata 2,93 pada siklus I dengan kategori cukup meningkat pada siklus II dengan peningkatan sebesar 0,45 menjadi 3,38 nilai rata-ratanya terkategori baik.

\section{Hasil Belajar Siswa}

Hasil belajar adalah kemampuan-kemampuan yang dimiliki siswa setelah menerima pengalaman belajarnya. Hasil belajar memiliki beberapa aspek (kognitif, afektif, dan psikomotorik). Namun dalam penelitian ini penilaian sebagai indikator hasil belajar hanya diambil dari hasil tes formatif pada aspek kognitif. Mengenai perkembangan hasil belajar siswa dari tindakan kelas yang telah dilakukan dalam penelitian ini dapat dilihat pada tabel berikut ini :

Tabel 4. Rekapitulasi Hasil Belajar Siswa

\begin{tabular}{|c|c|c|c|}
\hline Keterangan & Pra Siklus & Siklus I & Siklus II \\
\hline Tuntas & 18 & 22 & 27 \\
\hline Belum Tuntas & 14 & 10 & 5 \\
\hline Nilai Tertinggi & 87,5 & 90 & 95 \\
\hline
\end{tabular}


Wahana Didaktika Vol. 16 No.3 September 2018 : 321-329

\begin{tabular}{|c|c|c|c|}
\hline Keterangan & Pra Siklus & Siklus I & Siklus II \\
\hline Nilai Terendah & 40 & 40 & 50 \\
\hline$\frac{\sum X}{N}$ & $2152,5 / 32$ & $2304,2 / 32$ & $2498,3 / 32$ \\
\hline $\bar{x}$ & 67,58 & 72,01 & 78,07 \\
\hline $\begin{array}{c}\text { Ketuntasan } \\
\text { Klasikal }\end{array}$ & $56,25 \%$ & $68,75 \%$ & $84,38 \%$ \\
\hline
\end{tabular}

\section{SIMPULAN}

Berdasarkan hasil penelitian yang telah dijabarkan sebelumnya, dapat disimpulkan bahwa penerapan model Visualization Auditory Kinestetic (VAK) dapat diandalkan sebagai teknik pembelajaran yang baik untuk meningkatkan hasil belajar siswa. Berikut adalah paparan kesimpulan dari penelitian yang telah dilakukan:

1. Dalam pelaksanakan pembelajaran model Visualization Auditory Kinestetic (VAK), hasil pengamatan terhadap guru dan siswa diantaranya siklus I dengan pengamatan LPKG siklus I mencapai 3,70 (Sangat Baik) dan observasi siswa siklus I mencapai 2,93 (Baik). siklus II dengan pengamatan LPKG siklus II mencapai 3,97 (Sangat Baik) dan observasi siswa siklus II mencapai 3,38 (Sangat Baik).

2. Terdapat peningkatan hasil belajar yang tampak dari evaluasi hasil belajar pra siklus dengan presentase ketuntasan $56,25 \%$ dengan nilai rata-rata 67,58 mengalami peningkatan pada siklus I dengan presentase ketuntasan hasil belajar adalah 68,75\% dengan nilai rata-rata siswa 72,01. Pada siklus II hasil belajar siswa juga mengalami peningkatan presentase ketuntasan belajar menjadi $84,38 \%$ dengan rata-rata nilai siswa yaitu 78,07. Berdasarkan hasil tersebut dapat diketahui bahwa peningkatan hasil belajar siswa dari pra siklus ke siklus I sebesar $12,50 \%$ dan siklus I ke siklus II sebesar 15,63\%. 
Penerapan Model Visualization ....(Isnania Lestari)

\section{DAFTAR PUSTAKA}

Arikunto, S. (2010). Prosedur Penelitian. Jakarta: Rineka Cipta.

Arikunto, S dkk. (2014). Penelitian Tindakan Kelas. Jakarta: Bumi Aksara.

Huda, M. (2014). Model-Model Pengajaran dan Pembelajaran. Yogyakarta: Pustaka Belajar.

Mulyasa, E. (2011). Praktik Penelitian Tindakan Kelas. Bandung: Rosda

Shoimin, A. (2013). 68 Model Pembelajaran Inovatif dalam Kurikulum 2013. Yogyakarat: Ar-Ruzz Media. 